\title{
A mathematical modeling perspective on the advantages of single receptor type convergence in the olfactory glomeruli
}

\author{
Lakshmi Chandrasekaran ${ }^{1 *}, \mathrm{C}$ Ron $\mathrm{Yu}^{1,2}$ \\ From Twenty Second Annual Computational Neuroscience Meeting: CNS*2013 \\ Paris, France. 13-18 July 2013
}

Olfactory circuits in both insects and rodents are wired according to a pattern of convergence in which axons from olfactory sensory neurons expressing a single receptor type (SRT) project into the same glomerulus. This permits the representation of individual olfactory receptors in a topographical map in the brain ([1], [2], [3]). The functional advantage offered by a SRT convergence pattern is an open question. We analyze a simple mathematical model based on the anatomy of the olfactory bulb. The model contains two interconnected layers of glomeruli and mitral cells. We use the mathematical model to qualitatively explore the impact on odor coding and discrimination by changing the projection pattern from SRT to multiple receptor type (MRT) input patterns. We predict that for odors activating similar patterns, the MRT network is not able to separate response patterns as well as the SRT network. The mathematical prediction is in good qualitative agreement with experimental findings. Our predictions also indicate that sparseness of input patterns and overall network size are key parameters in determining how well the SRT network performs in discrimination of odors. Future work will focus on verification of these additional predictions through biological experiments and also investigating the role of more realistic network models in influencing odor discrimination abilities of the SRT case.

\footnotetext{
Author details

${ }^{1}$ Stowers Institute for Medical Research, 1000 East $50^{\text {th }}$ Street, Kansas City, MO 64110, USA. ${ }^{2}$ Department of Anatomy and Cell Biology, University of
} Kansas Medical Center, Kansas City, KS 66160, USA.

\footnotetext{
* Correspondence: chandrasekaran.lakshmi@gmail.com

${ }^{1}$ Stowers Institute for Medical Research, 1000 East $50^{\text {th }}$ Street, Kansas City, MO 64110, USA
}

Full list of author information is available at the end of the article
Published: 8 July 2013

\section{References}

1. Mombaerts P, Wang F, Dulac C, Chao SK, Nemes A, Mendelsohn M, Edmonson J, Axel R: Visualizing an olfactory sensory map. Cell 1996, 87:675-686.

2. Resseler KJ, Sullivan SL, Buck LB: Information coding in the olfactory system: evidence for a stereotyped and highly organized epitope map in the olfactory bulb. Cell 1994, 79:1245-1255.

3. Vassar R, Chao SK, Sitcheran R, Nunez JM, Vosshall LB, Axel R: Topographic organization of sensory projections to the olfactory bulb. Cell 1994, 79:981-991.

doi:10.1186/1471-2202-14-S1-P428

Cite this article as: Chandrasekaran and Ron Yu: A mathematical modeling perspective on the advantages of single receptor type convergence in the olfactory glomeruli. BMC Neuroscience 2013 14(Suppl 1):P428.
Submit your next manuscript to BioMed Central and take full advantage of:

- Convenient online submission

- Thorough peer review

- No space constraints or color figure charges

- Immediate publication on acceptance

- Inclusion in PubMed, CAS, Scopus and Google Scholar

- Research which is freely available for redistribution
() Biomed Central
() Biomed Central

() 2013 Chandrasekaran and Ron Yu; licensee BioMed Central Ltd. This is an Open Access article distributed under the terms of the Creative Commons Attribution License (http://creativecommons.org/licenses/by/2.0), which permits unrestricted use, distribution, and reproduction in any medium, provided the original work is properly cited. 